ВІСНИК

ОДЕСЬКОГО НАЦІОНАЛЬНОГО

МОРСЬКОГО УНІВЕРСИТЕТУ
HERALD

OF THE ODESSA NATIONAL

MARITIME UNIVERSITY

№ 3 (63), 2020

УДК $629.5 \mathrm{E30}$

DOI 10.47049/2226-1893-2020-3-21-50

\title{
ИССЛЕДОВАНИЕ \\ ПАРОМОВ И ГРУЗОПАССАЖИРСКИХ СУДОВ ДЛЯ ДАЛЬНЕГО ВОСТОКА
}

\section{Г.В. Егоров}

д.т.н., профессор, генеральный директор

Морское инженерное бюро, Одесса, Украина

Аннотация. Проанализированы действующие и существовавщие ранее морские линии Дальнего Востока. Показаны возможные международные транспортные коридоры.

С учетом выполненного анализа грузовой и пассажирской базы, путевых условий и существующего флота спроектированы новые современные паромы и грузопассажирские суда проектов PV22, PV24, CNF11CPD, которые в настоящий момент строятся на различных судостроительных заводах. Четыре уже построенных судна проекта DCV47 типа «Сосновка» успешно работают на морских линиях на Камчатке. Они предназначены для перевозки генеральных, навалочных, контейнерных грузов на грузовой палубе, колесной и гусеничной техники накатным способом, рейдовой разгрузки и погрузки судов, доставки этих грузов на необорудованный берег с возможностью осушки на песчано-гравийном грунте и обеспечение горизонтальной выгрузки доставленных грузов с помощью носовой аппарели или судовым грузовым краном.

Путевые, погодные и ледовые условия линий, особенности пассажиропотока и грузопотока, сопряжения с другими видами транспорта настолько отличаются в каждом дальневосточном регионе, что, по сути, привели к созданию различных конщептов грузопассажсирских судов, которые отвечают этим ограничениям.

Сделан вывод, что развитие паромных линий на Дальнем Востоке придаст импульс развитию транспортной инфраструктуры региона, позволит обеспечить транспортную доступность отдаленных регионов, совершенствовать береговую часть паромных линий.

Ключевые слова: Дальний Восток, морские линии, паром, грузопассажирское судно, инфраструктура, сочиальная значимость.

(C) Егоров Г.В., 2020 
DOI 10.47049/2226-1893-2020-3-21-50

\section{ДОСЛІДЖЕННЯ \\ ПОРОМІВ І ВАНТАЖОПАСАЖИРСЬКИХ СУДЕН ДЛЯ ДАЛЕКОГО СХОДУ}

\section{Г.В. Сгоров}

д.т.н., професор, генеральний директор

Морське інженерне бюро, м. Одеса, Украӥна

Анотація. Проаналізовано діючі і ті, щуо раніше існували, морські лінії Далекого Сходу. Показано можливі міжнародні транспортні коридори.

3 урахуванням виконаного аналізу вантажної і пасажирської бази, шляхових умов $i$ існуючого флоту спроектовано нові сучасні пороми $i$ вантажсопасажсирські судна проектів PV22, PV24, CNF11CPD, які зараз будуються на різних суднобудівних заводах. Чотири вже побудованих судна проекту DCV47 типу «Сосновка» успішно праџюють на морських лініях на Камчатиі. Вони призначені для перевезення генеральних, навалювальних, контейнерних вантажів на вантажній палубі, колісної та гусеничної техніки накатним способом, рейдового розвантаження та завантаження суден, доставки иих вантажів на необладнаний берег з можливістю осушення на піщано-гравійному трунті $i$ забезпечення горизонтального вивантаження доставлених вантажів за допомогою носової апарелі або судновим вантажним краном.

Шляхові, погодні та льодові умови ліній, особливості пасажиропотоку $i$ вантажопотоку, сполучення з іншими видами транспорту настільки відрізняються в кожному далекосхідному регіоні, щчо, по суті, привели до створення різних концептів вантажопасажирських суден, які відповідають цим обмеженням.

Зроблено висновок, щзо розвиток поромних ліній на Далекому Сходi приведе до розвитку транспортної інфраструктури регіону, дозволить забезпечити транспортну доступність віддалених регіонів, удосконалювати берегову частину поромних ліній.

Ключові слова: Далекий Схід, морські лінії, пором, вантажопасажирське судно, інфраструктура, соџіальна значимість.

UDC 629.5 E30

DOI 10.47049/2226-1893-2020-3-21-50

\section{INVESTIGATION OF FERRIES AND CARGO PASSENGER VESSELS FOR FAR EAST

\author{
G. Yegorov
}

Doctor of Technical Sciences, Professor, General Director

Marime Engineering Bureau, Odessa Ukraine 
ВІСНИК

ОДЕСЬКОГО НАЦІОНАЛЬНОГО

МОРСЬКОГО УНІВЕРСИТЕТУ № 3 (63), 2020
HERALD

OF THE ODESSA NATIONAL

MARITIME UNIVERSITY № 3 (63), 2020

Abstract. Existing and previously operated sea lines of the Far East are analyzed. Possible international transport corridors are shown.

Taking into account the analysis of the cargo and passenger base, way and existing fleet conditions, new modern ferries and cargo passenger vessels of PV22, PV24, CNF11CPD projects have been designed, which are currently being built at different shipyards. Four already built DCV47 vessels of «Sosnovka» type are successfully operating on sea lines in Kamchatka region. They are designed for the transportation of general, bulk, container cargoes on cargo deck, wheeled and tracked vehicles by rolling method, road unloading and loading of vessels, delivery of these cargoes to an unequipped coast with the possibility of drying on sand and gravel ground and ensuring horizontal unloading of the delivered cargo using the bow ramps or ship cargo crane.

Way, weather and ice conditions of the lines, specifics of passenger and freight traffic, intercrossing with other types of transport are so different in each Far Eastern region that, in fact, they have led to the creation of various concepts of cargo passenger vessels that meet these restrictions.

It is concluded that the development of ferry lines in the Far East will give an impact to the development of the transport infrastructure of the region, will ensure transport accessibility of remote regions, and improve the coastal part of ferry lines.

Keywords: the Far East, sea lines, ferry, cargo passenger vessel, infrastructure, social value.

Постановка проблемы. Сегодняшний интерес к паромным и пассажирским перевозкам на Дальнем Востоке абсолютно объективен.

При этом, по данным журнала «Эксперт» [1], только Сахалинская область при населении менее 500 тыс. человек выдает «на гора» валового регионального продукта на душу населения в 3,8 раза больше, чем в среднем по стране. Чукотский округ - при населении около 50 тыс. человек выдает «на гора» валового регионального продукта на душу населения в 2,79 раза больше, чем в среднем по стране. Камчатский край - при населении около 320 тыс. человек выдает «на гора» валового регионального продукта на душу населения в 1,11 раза больше. Магаданская область при населении около 150 тыс. человек выдает «на гора» валового регионального продукта на душу населения в 1,53 раза больше.

На долю морского транспорта в этих областях приходится более $90 \%$ всего грузопотока.

Доставка жителей и гостей регионов - либо авиацией, либо морем. Других вариантов нет.

Активизация создания новых судов для обеспечения транспортной доступности Дальнего Востока произошла во втором десятилетии XXI века. До этого основную нагрузку несли на себя «старые» суда, большинство из которых были построены еще в советское время. 
ВІСНИК

ОДЕСЬКОГО НАЦІОНАЛЬНОГО МОРСЬКОГО УНІВЕРСИТЕТУ № 3 (63), 2020
HERALD

OF THE ODESSA NATIONAL MARITIME UNIVERSITY № 3 (63), 2020

Целью статьи является рассмотрение и обсуждение истории и настоящего паромных и грузопассажирских линий Дальнего Востока XXI века, возможных международных транспортных коридоров, грузовой базы, обеспечения транспортной доступности для граждан отдаленных регионов, совершенствования береговой части паромных линий и путевых условий, возрастающих экологических требований и социальных задач, как основы для создания перспективных концептов новых паромов и грузопассажирских судов.

Изложение основного материала. Линии, которые обеспечивают паромы и грузопассажирские суда на Дальнем Востоке - это одновременно и механизм решения проблемы транспортной доступности, и завоз социально значимых грузов, это и необходимый для экономики Сахалина, Камчатки, Курил инструмент доставки топлива, товаров, сырья и продукции, это и «мосты», которые соединяют железную дорогу и автомобильный транспорт через водные преграды, такие как Татарский пролив.

Краткая актуальная схема этих линий приведена на рисунке 1.

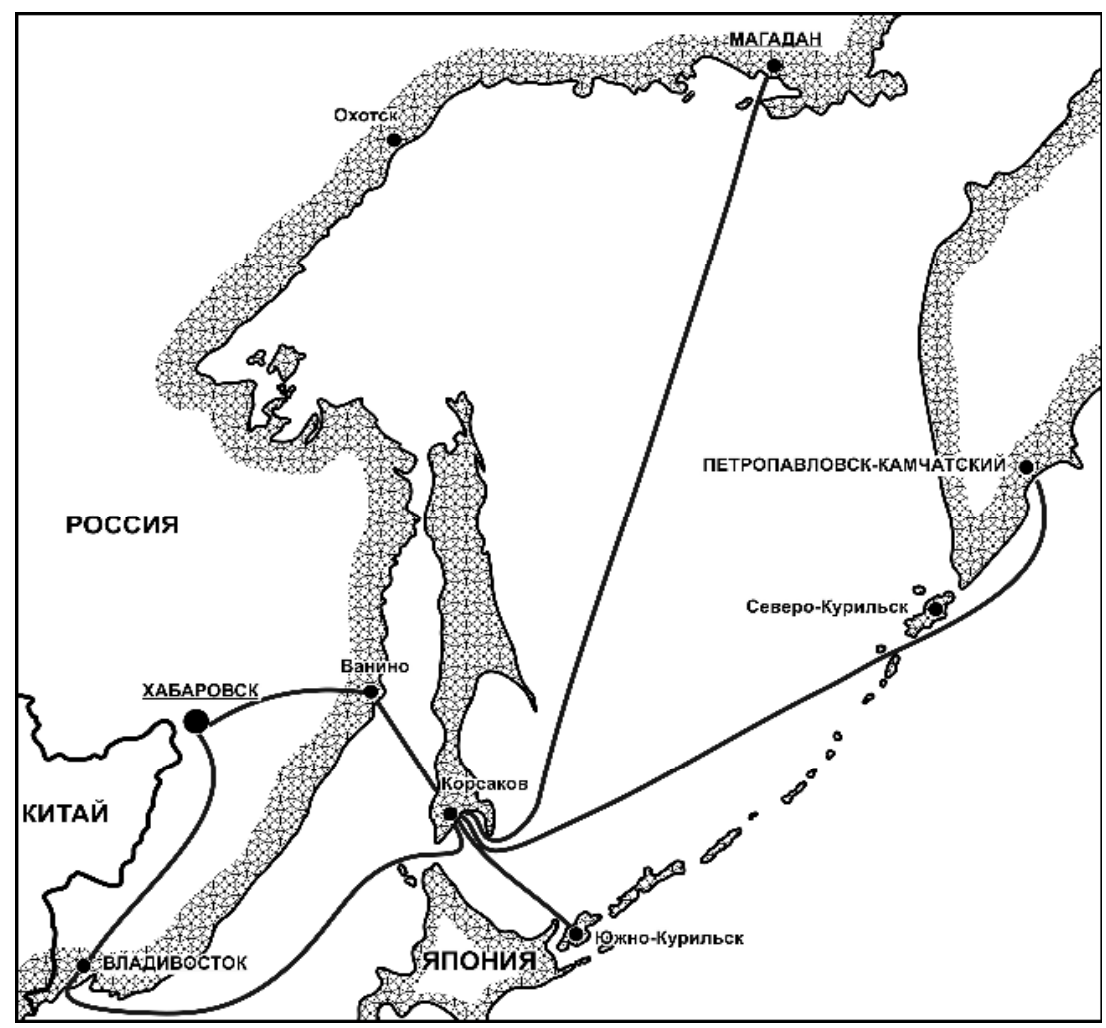

Рис. 1. Действующие дальневосточные линии, в том числе паромные и грузопассажирские 
На сегодняшний момент строятся уже пять новых судов, спроектированных Морским Инженерным Бюро - на Амурском заводе пассажирские автомобильно-железнодорожные паромы для линии ВаниноХолмск проекта CNF11CPD, на Невском заводе - грузопассажирские суда для Сахалина проекта PV22, на Окской судоверфи - грузопассажирское судно для Камчатки проекта PV24.

Собственно говоря, это было и раньше. До начала 90-х годов действовали многочисленные пассажирские линии (по состоянию на 1988 год):

1. Линия Дальневосточного морского пароходства (ДВМП) Владивосток - Петропавловск-Камчатский, без промежуточных остановок. В пути 4 суток. Отправление 1 раз в 10 дней. В ноябре и декабре маршрут пролегал через Пролив Лаперуза, в январе-апреле - через Сангарский пролив.

2. Приморская линия ДВМП (Владивосток - Светлая). Вдоль восточного побережья Приморья. В пути 3 суток. Заходы: Находка, Преображение, Валентин, Моряк-Рыболов, Ольга, Рудная Пристань, Пластун, Терней, Малая Кема, Амгу, Светлая. Отправление - один раз в неделю с ноября по апрель.

3. Линия ДВМП Сахалин - Курилы (Владивосток - Корсаков Курилы). В пути 4 суток. Заходы: Корсаков, Курильск, Касатка, МалоКурильск, Южно-Курильск, Корсаков. Отправление из Корсакова один раз в 3-4 дня, из Владивостока примерно один раз в месяц. С мая по октябрь.

4. Южно-Курильская линия ДВМП (Владивосток-Корсаков Курильск). В пути 4 суток. Заходы: Корсаков, Южно-Курильск, МалоКурильск, Курильск, Корсаков. Отправление один раз в 2-3 дня с мая по октябрь.

5. Северо-Курильская линия ДВМП (Владивосток-Корсаков Северо-Курильск). В пути 5 суток. Заходы: Корсаков, Южно-Курильск, Мало-Курильск, Курильск, Северо-Курильск, Курильск, Корсаков. Два рейса в год - в июне и августе.

6. Западно-Камчатская линия Камчатского пароходства (Петропавловск-Камчатский - Ича - Палана). В пути 3,5 суток. Заходы: СевероКурильск, Озерная, Кировск, Крутогорово, Ича, Хайрюзово, Палана. Отправление один раз в 10 дней с апреля по октябрь. Примерно половина рейсов следовала укороченным маршрутом до Ичи, в пути 2,5 суток.

7. Восточно-Камчатская линия Камчатского пароходства (Петропавловск-Камчатский - Пахача). В пути 4 суток. Заходы: Усть-Камчатск, Остров Беринга, Русаково, Оссора, Анапка, Корф, Пахача. Отправление один раз в 10 дней с мая по ноябрь.

8. Паромная линия Сахалинского пароходства Ванино - Холмск. Отправление один раз в сутки. 
При этом помимо перевозок обычных, регулярно осуществлялись перевозки подменных экипажей в районы промысла, обеспечивался завоз рабочих на рыбокомбинаты Курильских островов и Камчатки и перевозки других деловых пассажиров.

Перечислим наиболее известные пассажирские суда и паромы ДВМП, Камчатского и Сахалинского пароходств «советского периода».

Типа «Михаил Калинин» проекта 101 или Seefa 340 - 8 в ДВМП и «Петропавловск» в КМП (1958-1962 года постройки, Висмар, Германия). Длина х ширина х высота борта х осадка: 122,15 м х 16 м х 7,6 м х 5,18 м. Скорость 16,5 узлов. Пассажиры 265 - 330. Экипаж 134. Имелись каюты «люкс» и каюты на 1, 2, 3, 4 и 6 пассажиров. Музыкальный салон, ресторан, бар, кафе, бассейн, библиотека. Все каюты были дооборудованы санблоком (туалет, душ). Списаны до 1998 года.

Типа «Мария Ермолова» проекта 1454 - 5 в ДВМП (19751978 года постройки, Кралевица, Хорватия). Длина х ширина х высота борта х осадка: 100,02 м х 16,24 м х 7,0 м х 4,65 м. Скорость 17,2 узлов. Пассажиры 206 (216) в каютах с туалетом и душем и 28 (56) в креслах авиационного типа. Экипаж 83. Ресторан, музыкальный салон с баром, кафе. Трюм объемом 750 куб. м. Кран грузоподъемностью 3,2 тонны. Списаны до 2010 года.

Типа «Сахалин» проекта 1809 - 10 в СМП (1973-1992 года постройки, Калининград, Россия). Длина х ширина х высота борта х осадка: 127,3 м х 20,32 м х 14,7 м х 6,6 м. Скорость 16,8 узлов. Пассажиры 72 в каютах и 48 в авиационных креслах. Экипаж 41. Железнодорожных вагонов - 26. Семь списаны (до 2013 года). Эксплуатируется «Сахалин-8», «Сахалин-9» и «Сахалин-10» (последний в чисто грузовом варианте предназначен, в том числе для опасных грузов).

Анализ ветро-волновых и ледовых условий, а особенно пассажиропотока и сопряжения с другими видами транспорта настолько отличаются в каждом дальневосточном регионе, что, по сути, приводит к созданию различных концептов грузопассажирских судов, которые отвечают этим ограничениям.

Соответственно рассматриваются возможные направления и линии по регионам.

Сахалин. Паромная линия Ванино-Холмск. Более $75 \%$ всех грузовых перевозок и около 25\% пассажирских перевозок между островом Сахалин и материковой частью страны обеспечивает морская железнодорожная грузопассажирская паромная переправа «Ванино-Холмск».

Первая очередь существующей переправы Ванино-Холмск была торжественно открыта 27 июня 1973 года, вторая очередь - в 1985 году. Протяженность расположенной в Татарском проливе линии - 140 морских миль. Поскольку ширина сахалинской железнодорожной колеи 
ВІСНИК

ОДЕСЬКОГО НАЦІОНАЛЬНОГО

МОРСЬКОГО УНІВЕРСИТЕТУ № 3 (63), 2020
HERALD

OF THE ODESSA NATIONAL

MARITIME UNIVERSITY № 3 (63), 2020

1067 мм отличается от отечественной, в порту Холмск пока осуществляется замена тележек.

С 2003 года РЖД ведет переустройство всех сахалинских линий с 1067 мм на стандартную для отечественных железных дорог колею ширины 1520 мм: 865 км главных путей, 139 км станционных и 27 км подъездных путей, укладку 390 стрелочных переводов, реконструкцию 70 мостов и тоннелей. Модернизация островной инфраструктуры позволит существенно увеличить эффективность работы паромов.

Интересно отметить, что в действительности переправа, обеспечившая надежную связь между островом и материком, появилась еще в 50-е годы прошлого столетия. На нее были поставлены построенные в 1956 и 1958 году на Амурском судостроительном заводе паромы проекта 728 П «Забайкалье» и «Приамурье».

Сегодня на железнодорожной паромной линии Ванино-Холмск работают три парома первого ограниченного района плавания проекта 1809 «Сахалин-8», «Сахалин-9» и «Сахалин-10». На калининградском заводе «Янтарь» в период с 1972 год по 1992 год всего было построено десять таких паромов. Семь из них после полной выработки ресурса были списаны. Понятно, что срок службы оставшихся судов не безграничен и необходимы новые паромы для замены. По сути, реально в работе только два судна (один - в ремонте).

По оценкам специалистов ДНИИМФ, основными проблемами существующих дизель-электроходов типа «Сахалин» являются недостаточная мореходность; избыточный расход топлива на чистой воде от дополнительного сопротивления носового винта; недостаточная маневренность при заходе в порт Холмск из-за фактически одновальной установки и в силу отсутствия подруливающих устройств; плохой обзор из рубки; «развалы» электросхемы; низкая экономическая эффективность.

Недостаточная ледопроходимость и снижение эксплуатационных показателей работы действующих паромов типа «Сахалин» в связи с физическим износом корпуса и судового оборудования привели к тому, что время перехода парома в одну сторону увеличилось с 8 часов до 14-18 часов (обычное время движения парома по линии - 11-12 часов, зимой и при плохой погоде - 16-18 часов, доходит до 21 часа).

Как отмечают клиенты: «отправляются «по заполнению», время отхода и подхода судов варьируется в зависимости от наличия груза и погодных условий. Переправа считается, прежде всего, грузовой и работает по принципу «нет груза (то есть вагонов, машин) - паром не идёт», независимо от наличия пассажиров».

С конца 90-х годов, с открытием автомобильного сообщения из Ванино с городами Хабаровск и Комсомольск-на-Амуре Сахалинское пароходство приступило к перевозкам на линии не только железнодорожных вагонов, но и автотранспорта, в первую очередь автопоездов со скоропортящимися и другими потребительскими грузами, доля которых 
неуклонно растет. По оценкам экспертов, к 2025 году потребность в перевозках грузов между Сахалином и материком составит около 9,2 млн. тонн груза за счет увеличения сбыта угля из Углегорского района, необходимости завоза строительных материалов для новых объектов электроэнергетики и перерабатывающей промышленности.

Потенциальная база переправы составляет по году около 25 тыс. вагонов (особенно повлияет унификация колеи), 11-12 тыс. автомобилей (особенно после реконструкции автодороги Лидога - Ванино).

При этом оставшихся трех судов с учетом их ограничений по мореходности периодически не хватает для обработки заявленного объема груза уже сейчас. Например, в ноябре-декабре 2010 года ОАО «РЖД» было вынуждено объявить конвенцию - запрет погрузки грузов в адрес сахалинских потребителей, так как уже скопилось в ожидании погрузки на остров более 1100 вагонов. Причина - плохая погода, из-за которой паромы (тогда их было еще четыре) простояли 26 дней, а в остальные дни половину вместимости пришлось отдать автопоездам. И такие конвенции случаются в осенне-зимний период практически каждый год.

Именно поэтому наблюдается снижение перевозок - просто не на чем. Например, в 2019 году было перевезено груза в направлении Ванино-Холмск 1 млн. 196 тыс. тонн и обратно 1 млн. 184 тыс. тонн (при внутреннем потреблении области 2,2 млн. тонн груза в год), пассажиров 28,6 тыс. человек.

Основными конкурентами паромной линии Ванино-Холмск являются контейнерные линии, к примеру, Владивосток-Корсаков. Объем перевозок по данным линиям составляет порядка 800 тыс. тонн в год в сторону Сахалина (50 тыс. TEU). Тарифные ставки на указанных линиях в 3-4 раза выше по сравнению со ставками паромной линии. Несмотря на то, что ставка фрахта на контейнерных линиях существенно выше, чем на линии Ванино-Холмск, грузовладельцы выбирают контейнерные перевозки судами, которые надежнее и понятнее.

В 2012-2013 годах Морское Инженерное Бюро, во взаимодействии с ведущими отечественными и иностранными научными институтами, включая Акер Арктик технолоджи (рекомендации по обводам, испытания в ледовой бассейне), ЦНИИ морского флота (экспертиза технических решений на всех стадиях, формирование обводов, экономические расчеты и моделирование эксплуатации), Крыловским государственным научным центром (испытания буксировочные, самоходные, мореходные, а также проверочные в ледовом бассейне), проектно-конструкторским бюро вагонного хозяйства ОАО «РЖД» (проверка возможности перевозки подвижного состава на пароме), создало проект CNF11CPD - новый концепт пассажирского автомобильно-железнодорожного парома ледокольного типа неограниченного района плавания нового поколения с двухвальной четырехдвигательной силовой установкой и тремя подруливающими уст- 
ВІСНИК

ОДЕСЬКОГО НАЦІОНАЛЬНОГО МОРСЬКОГО УНІВЕРСИТЕТУ № 3 (63), 2020
HERALD

OF THE ODESSA NATIONAL MARITIME UNIVERSITY № 3 (63), 2020

ройствами для линии Ванино-Холмск, учитывающий опыт работы существующих судов и условия линии (см. научные результаты в [2-6]).

По этому проекту строятся два судна на Амурском заводе.

В ходе масштабных исследований было разработано четыре эскизных проекта (с вариациями архитектурно-конструктивного типа судно с оптимизированными ледокольными обводами и судно «двойного действия» с работой во льду кормой вперед, с классической пропульсией и с винто-рулевыми колонками) и два технических проекта (для варианта чисто грузового CNF11 и расширенного варианта с пассажирами и грузами, в том числе опасными CNF11CPD) - см. рисунки 2 и 3.

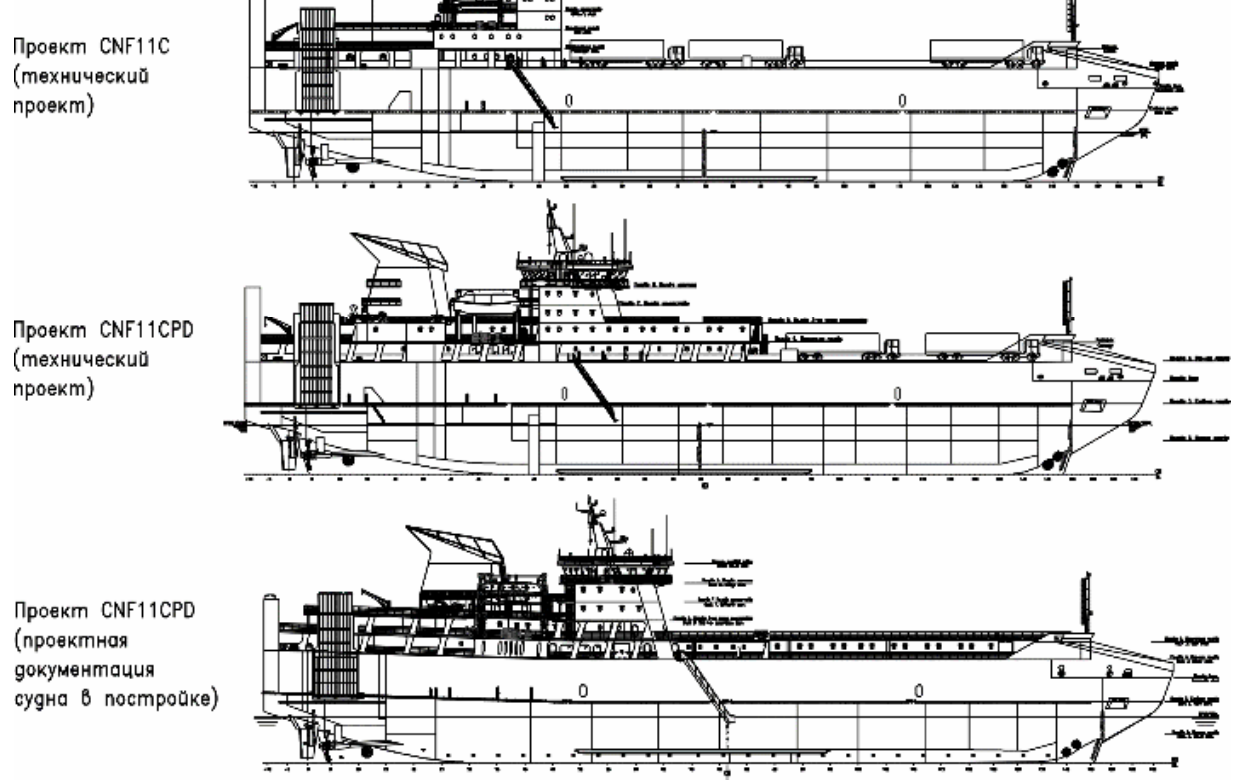

Pис. 2. Боковые виды-развитие конщепта CNF11CPD

Предполагается, что новые паромы будут работать с использованием существующих старых паромных причалов, и, какое-то время, параллельно с действующими паромами типа «Сахалин», постепенно их вытесняя.

Следовательно, схема накатки и расположения вагонов (четыре колеи по ширине), ширина парома, система соединения с мостом остается неизменной.

Существующие железнодорожные паромы имеют первый ограниченный район плавания. Новые паромы имеют неограниченный район плавания и соответственно не имеют ограничений по погоде. 
(технический

nрoekm)

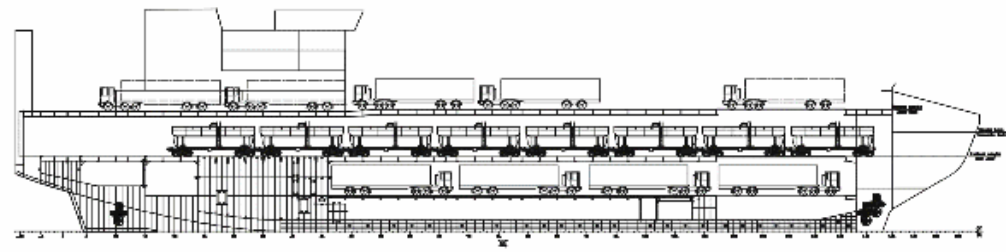

Проект CNF11CPD

(технический

nроекm)

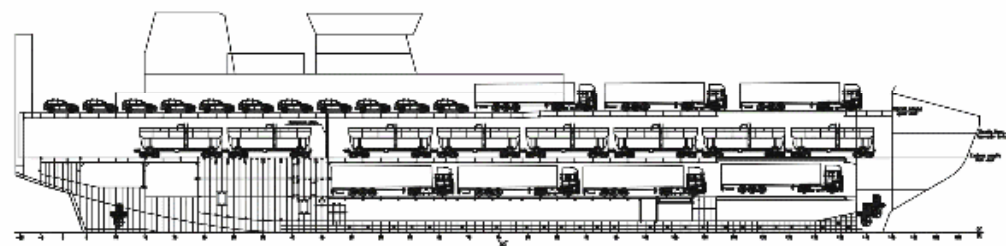

Проекm CNF11CPD

(провктная

gокументация

суgна В постройкө)

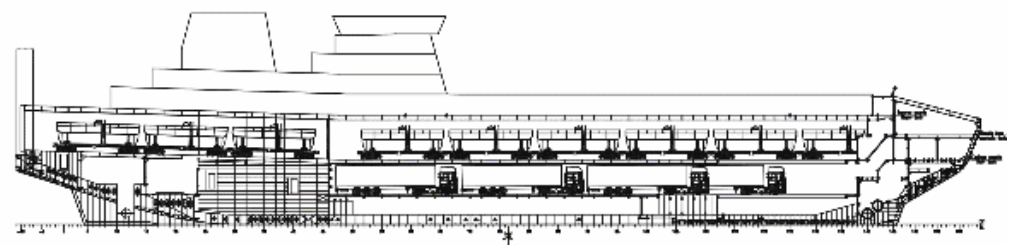

Рис. 3. Продольный разрез - развитие конщепта CNF11CPD

Паромы типа «Сахалин» имеют по ОДНОМУ винту ФИКСИРОВАННОГО шага в носу и в корме. Вполне нормальное решение для конца 60-х годов, когда паром проектировался (тогда это еще использовалось в практике судостроения из-за больших проблем с изготовлением мощных и надежных подруливающих устройств в СССР, сейчас же - это просто архаика).

В гидрометеорологическом отношении негативной особенностью Холмского морского торгового порта являются тягуны на внутренней акватории; стоячие волны, затрудняющие заход судов; течения вдоль берега, которые быстро разворачивают тихоходные суда на входе в порт. Вследствие этого обычной практикой в последнее время стал заход судов в порт, на повышенных скоростях хода, что повышает вероятность столкновений и навалов, создает дополнительное волнообразование и противоречит общим представлениям о безопасности плавания в портах. Поэтому паромы нового типа получили управляемость, обеспечивающую безопасный заход в порт Холмск.

Отсюда тактика захода в порт Холмск - проскочить на хорошем заднем ходу в акваторию порта (у него ведь нет возможности «парировать» боковые усилия от ветра, от волнения, от течения - винты ведь в ДП, соответственно, на малом ходу рули бесполезны - его может просто снести в сторону). 
ВІСНИК

ОДЕСЬКОГО НАЦІОНАЛЬНОГО

МОРСЬКОГО УНІВЕРСИТЕТУ № 3 (63), 2020
HERALD

OF THE ODESSA NATIONAL

MARITIME UNIVERSITY № 3 (63), 2020

Следует также отметить, что значительная часть установленного на паромах типа «Сахалин» оборудования снята с производства.

Тактика захода современного парома в порт Холмск в соответствии с его возможностями совершенно другая.

Новому парому для обеспечения его управляемости не требуется опасный заход в порт на высоких скоростях. Паром движется в порту кормой вперед на скоростях меньше 3 узлов, при которых не наблюдается снижение эффективности подруливающих устройств.

Площадь парусности нового парома (боковой профиль) в самом неблагоприятном варианте при неполной осадке 6,5 м и с автопоездами на верхней палубе составляет около $2250 \mathrm{~m}^{2}$. При самом неблагоприятном направлении ветра (перпендикулярно диаметральной плоскости) только с работающими подруливающими устройствами (тяга $3 \times 76$ кН) паром может противостоять ветру со скоростью 18 узлов с нулевым перемещением. С учетом сопротивления дрейфу и работы винто-рулевого комплекса (двухвальная установка) допустимая скорость такого ветра значительно возрастает.

Принятые решения позволяют обеспечить самостоятельную швартовку и длительное движение задним ходом по стесненной акватории портов Ванино и Холмск, проход ворот порта Холмск задним ходом на скорости, обеспечивающей устойчивое управление судном.

Для сведений, характеристики управляемости нового судна, нормируемые Правилами РС: параметр устойчивости на курсе $E_{1}=0,048$, параметр эффективности на мелководье $E_{2}=0,080$, параметр прямолинейности движения при штормовом ветре $E_{3}=0,079$. При этом характеристики устанавливаемых на судне рулей: нормативная эффективность одного руля $E_{p}=0,062$. Суммарная эффективность рулей судна составляет $2 \times E_{p}=0,124$. Таким образом, эффективность управляемости судна $0,124 / 0,080=1,55$, что более чем в 1,5 раза больше нормативно требуемой.

Ходовое время на линии Ванино-Холмск у парома составляет приблизительно 80-90 \% кругового рейса - примерно около 20 часов в сутки. Поэтому корпус получил обводы достаточно скоростного судна и одновременно обеспечивает сезонную самостоятельную работу в тяжелых льдах.

Скорость нового парома CNF11CPD составляет 18 узлов при $85 \%$ использованной мощности двигателей (существующие суда имеют скорость около 16 узлов). За счет хорошо известного (для европейских паромов) решения на проекте CNF11CPD на каждый винт работают по два главных двигателя, что позволяет на экономическом ходу держать скорость в 12 узлов, на полном - 18 узлов. Обводы корпуса были разработаны с помощью компьютерного моделирования и проверены в опытовых бассейнах ЦНИИ Крылова и Акер Арктик. 
Особенностью функционирования паромной переправы ВаниноХолмск является сезонная самостоятельная работа в сложных ледовых условиях - 3-4 месяца в году на коротком участке перехода (в районе п. Ванино) складывается тяжелая ледовая обстановка. При появлении «ледовой реки» в порт Ванино разрешается заход судов с ледовой категорией ARC 5 и выше.

Но, как показывает происшествие с танкером «Игрим» с ледовой категорией УЛ (ARC 5) и мощностью главного двигателя 7,8 МВт, когда он был прижат «ледовой рекой» к припою на дистанции 3 кабельтова от береговой черты, в тяжелых случаях требуется категория УЛА (ARC 7).

В зиму 2011-2012 года простои 143 судов в ожидании погоды составили 299 суток, в 2013 году ледовые ограничения по классу объявлялись на 52 дня, в 2014 году - на 26 дней.

Как показывает анализ условий эксплуатации, во время зимневесенней навигации перспективное судно должно двигаться со скоростью около 6-8 узлов в ровном льду толщиной $80 \mathrm{~cm} \mathrm{и} \mathrm{со} \mathrm{скоростью} \mathrm{около}$ 3 узлов в ровном льду толщиной 1,0 м.

В итоге, в результате проведенных исследований получены характеристики ходовых качеств автомобильно-железнодорожного парома проекта CNF11CPD в ледовых условиях: по результатам испытаний в бассейне предельная ледопроходимость на переднем ходу при скорости $V=3$ узла составит 1,16 метров, при скорости $V=6$ узлов составит 0,84 метра, на заднем ходу при скорости $\mathrm{V}=1,5$ узла составит 0,68 м. Кроме того, конструктивно носовая и кормовая оконечности спроектированы по более высокой ледовой категории (Arc 7). В совокупности с ледопроходимостью на уровне ледокола Icebreaker6 это позволяет обеспечить (в отличие от существующих судов) самостоятельную работу нового парома в тяжелых ледовых условиях на коротком участке перехода (примерно до 30 миль в районе п. Ванино). В свою очередь это позволит избежать значительных простоев парома в ожидании общей ледокольной проводки, либо избыточных расходов в случае индивидуальной проводки.

В свое время паромная переправа строилась для обслуживания железнодорожных перевозок, но в последнее время все большую часть на паромных маршрутах стала занимать перевозка автомобильного транспорта. Появился новый вид груза - тяжелые трейлеры (фуры) и легковые автомобили. В связи со строительство автодороги Лидога-Ванино доля перевозок автомобильного транспорта будет расти. Помимо перевозок автомобилей и трейлеров у грузоотправителей имеется еще один потенциально новый для паромной линии вид груза: контейнеры и роллтрейлеры с тяжелой техникой. Поэтому при сохранении функции перевозки железнодорожных вагонов (протяженность рельсовых путей 440 пог. м при 420 на существующем - это 32 вагона длиной 12020 мм или 26 вагонов длиной 14730 мм), в 1,8 раза выросла вместимость по 
ВІСНИК

ОДЕСЬКОГО НАЦІОНАЛЬНОГО

МОРСЬКОГО УНІВЕРСИТЕТУ № 3 (63), 2020
HERALD

OF THE ODESSA NATIONAL

MARITIME UNIVERSITY № 3 (63), 2020

автомобилям (700 пог. м против 394 на существующем). В итоге на новом судне можно разместить 39 грузовых автомобилей с полуприцепами, имеющим длину 12-13,5 м и дополнительно 9 легковых автомобилей.

Для обеспечения суточного рейса судна и соблюдения постоянного расписания требуется ограниченное время стоянки судна в порту, т.е. полная грузовая и пассажирская обработка судна должна осуществляться в течение 2 часов. Для этого на судне применяется кормовая схема накатной грузообработки посредством берегового железнодорожного моста.

Помимо кормовой схемы грузообработки, однозначно привязанной к терминалам портов Ванино и Холмск, установлена бортовая рампа для работы с накатной техникой прямо на причал, что позволяет применять новое судно, например, для коммерческих рейсов в Японию. В концепт заложена возможность работы по загрузке автопоездов и легковых автомобилей непосредственно на верхнюю палубу парома с береговых эстакад, которые предполагаются построить во время реконструкции терминалов линии.

Пассажировместимость существующих паромов востребована полностью, так как из-за высокой стоимости авиабилетов именно паром является единственно возможным способом пассажирских сообщений для большинства населения Сахалина (с учетом туманов, которые иногда бывают до 3 недель).

Выбранное в новом проекте количество пассажиров (200 человек) отражает пиковую потребность линии в сезон отпусков и назначено по предложению правительства Сахалинской области, которому принципиально важно обеспечить решение социальной задачи по отдыху населения региона. Из 200 пассажиров 112 размещено в каютах и 88 - в креслах салона.

Установленное на судно оборудование позволяет работать на переходе как на полных, так и на долевых режимах нагрузки, проводить требуемое техническое обслуживание главных двигателей без вывода парома из эксплуатации.

Таким образом, Морским Инженерным Бюро был создан проект CNF11CPD пассажирского автомобильно-железнодорожного паромаледокола нового поколения для линии «Ванино-Холмск», который обеспечивает по сравнению с существующими судами типа «Сахалин»:

- повышенные грузовые свойства (вместимость по грузовикам в 1,8 раза больше);

- не имеет ограничений по погоде (неограниченный район плавания);

- может работать в тяжелых ледовых условиях (во льду толщиной 80 см скорость около 6-8 узлов); 
- в состоянии выполнять самостоятельные (несколько раз в сутки) швартовки без буксирного обеспечения, длительное движение задним ходом по стесненной акватории порта Холмск;

- выдерживает суточный цикл кругового рейса (скорость в эксплуатации 18 узлов); работ.

- 2-х часовую стоянку при выполнении погрузочно-разгрузочных

Новый концепт CNF11CPD перевозит до 200 пассажиров и может перевозить опасные грузы вместе с перевозкой пассажиров.

При этом паромная линия в действительности состоит из двух «крыльев» - морской (т.е. парома, о котором было сказано выше) и береговой.

Паромная переправа Ванино-Холмск была открыта 47 лет назад и давно нуждалась в реконструкции.

В соответствии с техническим заданием в 2012 году предполагалось существенная модернизация береговой части, которая включала разработку новых мостов с переносом устоев и переукладкой путей, а также дноуглублением, что позволяло увеличить габаритную ширину паромов до 22,6 м и осадку до 7,0 м.

Кроме того, планировалось к береговым мостам добавить береговые эстакады для погрузки на верхнюю палубу, что позволило бы разделить поток железнодорожных вагонов (они бы перемещались по мосту) и автомобилей (по эстакаде) и тем самым ускорить процесс погрузкивыгрузки и сделать его более безопасным.

Однако потом с целью сокращения расходов на береговую часть вместо новых мостов решили реконструировать (сохранить) существующие мосты и отказаться от эстакады, соответственно на следующем этапе проектирования судна (проектная документация судна в постройке) Морское Инженерное Бюро использовало в своем концепте CNF11CPD прежние габаритные размеры по ширине и осадке.

В сентябре 2020 года ФГУП «Росморпорт» заключило с ФГБУ «Морспасслужба» контракт на такую реконструкцию инфраструктуры автомобильно-железнодорожной паромной переправы Ванино-Холмск. «Реконструкция обеспечит безопасную и надежную эксплуатацию паромной переправы. Целью работ является не только реконструкция действующей первой очереди паромного комплекса, но и восстановление работоспособности очереди № 2. Переправа «Ванино-Холмск» по итогам реализации проекта сможет принимать паромы нового типа повышенной вместимости (проект CNF11CPD)» - уточнил заместитель гендиректора по капитальному строительству ФГУП «Росморпорт» Владислав Рассыхин.

Гидротехнические работы по реконструкции береговой части паромной линии будут выполнять в два этапа. 
ВІСНИК

ОДЕСЬКОГО НАЦІОНАЛЬНОГО

МОРСЬКОГО УНІВЕРСИТЕТУ

№ 3 (63), 2020
HERALD

OF THE ODESSA NATIONAL

MARITIME UNIVERSITY № 3 (63), 2020

Первая очередь - причал № 1 - береговой устой и траншея для передвижения моста; левый морской устой с корневым выпуском; правый морской устой; образующее ложе парома; центральный пункт управления; подъемно-переходной мост; подъемные механизмы; въезд на причал; пассажирский трап.

Вторая очередь - причал № 3; причал № 4; береговой устой; два промежуточных устоя; левый морской устой с корневым выпуском; правый морской устой; образующее ложе парома; центральный пункт управления; подъемно-переходной мост; подъемные механизмы; въезд на причал; пассажирский трап; насыпная дамба сопряжения моста с берегом.

Общие характеристики паромов для линии Ванино-Холмск приведены в таблице 1.

Таблица 1

Железнодорожный паром проекта CNF11CPD -

Характеристики на разных стадиях проектирования

\begin{tabular}{|c|c|c|c|}
\hline $\begin{array}{l}\text { Наименование } \\
\text { характеристики }\end{array}$ & $\begin{array}{c}\text { Проект } \\
\text { CNF11C } \\
\text { (технический } \\
\text { проект) }\end{array}$ & $\begin{array}{c}\text { Проект } \\
\text { CNF11CPD } \\
\text { (технический } \\
\text { проект) }\end{array}$ & $\begin{array}{c}\text { Проект } \\
\text { CNF11CPD } \\
\text { (проектная } \\
\text { документация } \\
\text { судна } \\
\text { в постройке) }\end{array}$ \\
\hline Тип & \begin{tabular}{|l} 
Автомобильно- \\
железнодорож- \\
ный паром без \\
перевозки \\
пассажиров
\end{tabular} & $\begin{array}{c}\text { Пассажирско- } \\
\text { автомобильно- } \\
\text { железнодорож- } \\
\text { ный паром }\end{array}$ & $\begin{array}{c}\text { Пассажирско- } \\
\text { автомобильно- } \\
\text { железнодорож- } \\
\text { ный паром }\end{array}$ \\
\hline $\begin{array}{l}\text { Класс Российского Морского } \\
\text { Регистра Судоходства }\end{array}$ & $\begin{array}{c}\text { KM } \circledast \text { Arc5 } \\
\text { AUT1-C Ro-ro } \\
\text { ship }\end{array}$ & \begin{tabular}{|c|} 
KM $\circledast$ Arc5 \\
AUT1-ICS \\
OMBO ANTI- \\
ICE ECO Ro- ro \\
passenger ship
\end{tabular} & $\begin{array}{l}\text { KM } \otimes \text { Arc5 } \\
\text { AUT1-ICS } \\
\text { OMBO ANTI- } \\
\text { ICE ECO Ro-ro } \\
\text { passenger ship }\end{array}$ \\
\hline Длина габаритная, м & 131,00 & 131,00 & 131,00 \\
\hline Ширина габаритная, м & 22,60 & 22,60 & 20,32 \\
\hline Ширина расчетная, м & 22,20 & 22,20 & 19,92 \\
\hline Высота борта до ГП, м & 10,10 & 10,10 & 8,80 \\
\hline Высота борта до ВП, м & 16,15 & 16,15 & 14,80 \\
\hline Количество грузовых палуб & 3 & 3 & 2 \\
\hline Осадка, м & 7,00 & 7,00 & 6,60 \\
\hline Мощность ГД, кВт & $4 \times 4640$ & $4 \times 4640$ & $4 \times 4000$ \\
\hline Скорость максимальная, узл & 18,0 & 18,0 & 18,0 \\
\hline $\begin{array}{l}\text { Экипаж и обслуживающий } \\
\text { персонал, чел }\end{array}$ & 23 & 35 & 35 \\
\hline
\end{tabular}




\begin{tabular}{c|c} 
ВІСНИК & HERALD \\
ОДЕСЬКОГО НАЦІОНАЛЬНОГО & OF THE ODESSA NATIONAL \\
МОРСЬКОГО УНІВЕРСИТЕТУ & MARITIME UNIVERSITY \\
№ $3(63), 2020$ & $№ 3(63), 2020$ \\
\hline \hline
\end{tabular}

Продолжение табл. 1

\begin{tabular}{|c|c|c|c|c|}
\hline \multicolumn{2}{|c|}{ Количество пассажиров, чел. } & 12 & 150 & 200 \\
\hline \multicolumn{2}{|c|}{$\begin{array}{l}\text { Протяженность рельсовых } \\
\text { путей, м }\end{array}$} & 440 & 440 & 440 \\
\hline \multicolumn{2}{|c|}{$\begin{array}{l}\text { Протяженность полос для } \\
\text { автотехники, м (в отсутствии } \\
\text { жд вагонов) }\end{array}$} & 1180 & 1036 & 700 \\
\hline \multicolumn{2}{|c|}{$\begin{array}{l}\text { Количество ж/д вагонов дли- } \\
\text { ной } 12020 \text { мм (по } 77 \text { т) перево- } \\
\text { зимых на главной палубе, шт. }\end{array}$} & 30 & 30 & 32 \\
\hline \multicolumn{2}{|c|}{$\begin{array}{l}\text { Количество ж/д вагонов } \\
\text { длиной } 13920 \text { мм перевози- } \\
\text { мых на главной палубе, шт. }\end{array}$} & 26 & 26 & 26 \\
\hline \multicolumn{2}{|c|}{$\begin{array}{l}\text { Количество ж/д вагонов } \\
\text { длиной } 14730 \text { мм перевози- } \\
\text { мых на главной палубе, шт. }\end{array}$} & 24 & 24 & 26 \\
\hline \multirow{4}{*}{\begin{tabular}{|l|} 
Количество пере-- \\
возимых автосо- \\
ставов совместно \\
с перевозкой ж/д \\
вагонов на глав- \\
ной палубе, шт. \\
\end{tabular}} & $\begin{array}{l}\text { на главной } \\
\text { палубе }\end{array}$ & 4 & 4 & 3 \\
\hline & в трюме & 11 & 11 & 12 \\
\hline & $\begin{array}{l}\text { на верхней } \\
\text { палубе }\end{array}$ & 18 & 10 & - \\
\hline & Всего & 33 & 25 & 15 \\
\hline \multicolumn{2}{|c|}{$\begin{array}{l}\text { Количество перевозимых } \\
\text { автосоставов (по } 55 \text { т) без } \\
\text { перевозки ж/д вагонов, шт. }\end{array}$} & 56 & 48 & 39 \\
\hline \multicolumn{2}{|c|}{$\begin{array}{l}\text { Количество легковых автомо- } \\
\text { билей }(1,5 \text { т) перевозимых } \\
\text { совместно с одним из выше- } \\
\text { перечисленных вариантов, шт. }\end{array}$} & 28 & 28 & $\begin{array}{l}9 \text { (совместно с } \\
\text { автосоставами) }\end{array}$ \\
\hline \multicolumn{2}{|c|}{$\begin{array}{l}\text { Экипаж и обслуживающий } \\
\text { персонал, чел. }\end{array}$} & 23 & 35 & 35 \\
\hline \multicolumn{2}{|c|}{$\begin{array}{l}\text { Количество пассажиров } \\
\text { (каютных), чел. }\end{array}$} & 12 & 100 & 112 \\
\hline \multicolumn{2}{|c|}{$\begin{array}{l}\text { Количество пассажиров } \\
\text { (салонных), чел. }\end{array}$} & - & 50 & 88 \\
\hline \multicolumn{2}{|c|}{ Тип пассажирских кают } & $\begin{array}{c}\text { Все каюты для } \\
\text { пассажиров с } \\
\text { естественным } \\
\text { освещением }\end{array}$ & $\begin{array}{c}\text { Все каюты для } \\
\text { пассажиров с } \\
\text { естественным } \\
\text { освещением }\end{array}$ & $\begin{array}{c}\text { Все каюты для } \\
\text { пассажиров с } \\
\text { естественным } \\
\text { освещением }\end{array}$ \\
\hline
\end{tabular}

Сахалин. Курилы. Курильские острова, входящие в состав Сахалинской области, простираются на 1200 км от южной оконечности Камчатки в юго-западном направлении до острова Хоккайдо (Япония) и 
включают в себя 30 островов. Население проживает постоянно только на Парамушире, Итурупе, Кунашире и Шикотане.

На сегодняшний день на линиях Сахалин - Южные и Средние Курилы (острова Кунашир, Шикотан, Итуруп), Камчатка-Северные Курилы (остров Парамушир) в эксплуатации осталось всего два грузопассажирских судна:

1. Грузопассажирское судно «Игорь Фархутдинов». Проект В-961. Типа «Анна Ахматова». 1991 года постройки (Гдыня, Польша). Длина х ширина х высота борта х осадка: 88,98 м х 17,61 м х 10,30 м х 5,30 м. Скорость 14,3 узлов. Ледовый класса UL (по новому Arc 5). Пассажиры 150 в 2-х и 4-х местных каютах с туалетом и душем. Экипаж 49. Трюм объемом 208 куб. м. Кран грузоподъемностью 3,2 тонны.

2. Грузопассажирское судно «Гипанис». Проект 16151. 1992 года постройки Хабаровского завода. Длина х ширина х высота борта х осадка: 55,76 м х 9,51 м х 5,16 м х 4,22 м. Скорость 12,2 узла. Ледовый класса L2 (по новому Iсе 3 ). Пассажиры - 36 в каютах. Кран грузоподъемностью 3,0 тонны.

Мнение пользователей было сформулировано в запросе [7] 20 сентября 2013 года в Сахалинскую областную Думу: «Островитяне очень долго ждали покупки судна на острова. Нам сообщали не однократно, что нет аналога Игорю Фархудинову. Дело в том, что нет возможности привозить на острова и продукты, в основном скоропорт (так в оригинале). С осени идет ограничение в доставке продовольствия, так как грузовые суда грузятся по 1-2 неделе и идут в зависимости от погоды по 2-3 недели. Но осенью всегда шторма. Вам даже не представить себе, как сложно с осени и до весны порадовать свежими фруктами или молочной продукцией население острова и детей. Зимой грузовые суда не ходят по островам с 3 января до 20 апреля ... или идут 1 раз в месяц ... Нам надо удобное судно, ледокольного плана, которое сможет обеспечить и перевозку пассажиров и перевозку ГРУЗА на остров».

В 2009 году судно «Игорь Фархутдтинов» перевезло 17130 человек. Примерно с мая по октябрь на судне заняты все места, в остальное время заполнение неполное.

В 2015 году общий объем перевозок составил 24 тысячи человек. Согласно ФЦП «Социально-экономическое развитие Курильских островов (Сахалинская область) на 2016-2025 годы после ввода новых судов ожидается увеличение пассажиропотока до 70,5 тыс. человек к 2025 году.

Кроме того, на регулярной линии Сахалин - Курилы поставили грузовое судно «КДН-1».

Главные размерения новых судов ограничиваются условиями захода в порты Курильских островов, судно должно иметь собственными средствами погрузки/выгрузки на необорудованные кранами причалы. Круглогодичная эксплуатация судна, в том числе, в условиях Охотского моря определяет расчетные температурные режимы и ледовые усиления. 
Например, как сообщало 8 февраля 2018 года РБК: «Теплоход «Игорь Фархутдинов», который шел с курильского острова Шикотан в сахалинский город Корсаков, застрял во льдах при выходе из Кунаширского пролива. Об этом сообщил дежурный капитан-координатор Морского спасательного подцентра в Южно-Сахалинске, передает ТАСС.

«У нас есть информация, что теплоход «Игорь Фархутдинов», который шел в Корсаков, застрял во льдах», - сказал собеседник агентства.

Как сообщили власти Сахалинской области, судно вышло с Курил вечером 5 февраля. Спустя три дня на траверзе японского города Момбецу теплоход встретил плотные льды толщиной до полутора метров. На его борту находятся 127 пассажиров и 42 контейнера».

Исполняя ФЦП «Социально-экономическое развитие Курильских островов на 2016-2025 годы», в августе 2018 года АО «Сахалинлизингфлот» по результатам тендера заказал два грузопассажирских судна с арктической категорией ARC4 для сообщения Сахалина и Курил проекта Морского Инженерного Бюро PV22 на Невском заводе.

Суда предназначены для перевозки 146 пассажиров, генеральных грузов, контейнеров (в т.ч. рефрижераторных) и автомобилей между островом Сахалин и Курильскими островами и оборудовано грузовым краном с возможностью выполнять грузовые операции на необорудованном берегу.

Новый концепт проекта PV22 имеет улучшенную ледопроходимость, так как он был выполнен на базе арктического спасателя проекта MPSV07 [8], улучшенные маневренные качества по сравнению с существующими судами за счет подруливающего устройства и 2 винтов. Объем трюма - 895 куб. м (против 208-215 куб. м. на существующих судах). Судно имеет возможность перевозки 24 контейнеров, в том числе 8 рефрижераторных и 6 легковых автомобилей на палубе. Резервирование движения обеспечено за счет двухвальной двухдвигательной установки. Имеются каюты для людей с ограниченными физическими возможностями.

Длина наибольшая - 75,00 м. Длина расчетная - 69,72 м. Ширина габаритная $-16,00$ м. Ширина расчетная $-15,50$ м. Высота борта $-6,70$ м.

Пассажиры размещаются в каюте класса люкс для пассажиров с одной койкой, с индивидуальным санузлом и душем; 30 двухместных/четырёхместных кают для пассажиров, с индивидуальным санузлом и душем (включая 1 каюту для 1-2-х пассажиров с ограниченными способностями и сопровождающего); 6 четырехместных кают, с индивидуальным санузлом и душем; каюте матери и ребенка $(+2$ каюты из числа двухместных/четырёхместных кают для пассажиров отвечают требованиям, предъявляемым к каютам матери и ребенка). Общее количество стационарных спальных мест - 86/146 (двухместное/четырёхместное раз- 
мещение). Ресторан для пассажиров для питания в две смены (на 74 места).

При осадке 5,00 м дедвейт судна около 1830 тонн. Груз размещается в трюме объемом 895 куб. метров и на палубе, в том числе опасные грузы в упаковке.

Для выгрузки груза установлен грузовой кран грузоподъемностью до 30,5 тонн при вылете стрелы от 12 м до 18 м (против кранов грузоподъемностью 2,5-3,5 тонн на существующих судах).

Мощность главных двигателей 2 х 1800 кВт. Скорость 14,2 узла. Автономность 15 суток.

Главные характеристики судна проекта PV22 в сравнении с теми судами, которое оно будет менять, приведены в таблице 2.

Общее расположение грузопассажирского судна проекта PV22 приведено на рисунке 4.

В вебинаре «Все паромы России: Дальний Восток» эксперт Софья Каткова специально отметила уникальные возможности грузопассажирских судов проекта PV22 (количество пассажиров, контейнеры, мощный кран и серьезная ледовая категория), которые позволяют им работать для доставки людей и грузов в отдаленные месторождения Дальнего Востока, в том числе северного Сахалина и Севера.

Таблииа 2

Сравнение характеристик существуюших пассажирских судов и судна проекта PV22

\begin{tabular}{|c|c|c|c|c|}
\hline $\begin{array}{c}\text { Наименование } \\
\text { характеристики }\end{array}$ & $\begin{array}{c}\text { «Игорь } \\
\text { Фархутдинов» }\end{array}$ & $\begin{array}{l}\text { «Пола- } \\
\text { рис» }\end{array}$ & $\begin{array}{c}\text { «рофессор } \\
\text { Хромов» }\end{array}$ & $\begin{array}{l}\text { Проект } \\
\text { PV22 }\end{array}$ \\
\hline 1 & 2 & 3 & 4 & 5 \\
\hline Год постройки & 1990 & 1968 & 1983 & \\
\hline Длина наибольшая, м & 89.98 & 70.56 & 71.06 & 75.00 \\
\hline Длина расчетная, м & 78.45 & 63,00 & 64,30 & 69.72 \\
\hline Ширина габаритная, м & 17.61 & 13,54 & 12.82 & 16.00 \\
\hline Ширина расчетная, м & 17.20 & 13,50 & 12.80 & 15.50 \\
\hline Высота борта, м & 10.30 & 5,60 & 6.45 & 6.70 \\
\hline Осадка по ЛГВЛ, м & 5.30 & 4,40 & 4.50 & 5.00 \\
\hline $\begin{array}{l}\text { Дедвейт при осадке по } \\
\text { ЛГВЛ, т }\end{array}$ & 815 & 556 & 620 & 1829 \\
\hline Валовая вместимость GT & 4575 & 2097 & 1759 & 3034 \\
\hline Мощность ГД, кВт & $1 \times 3200$ & $2 \times 1405$ & $2 \times 1147$ & $2 \times 1800$ \\
\hline Скорость макс., узл & 14.3 & 13 & 14.0 & 14.2 \\
\hline Ледовый класс & UL & L1 & UL & Arc4 \\
\hline Пассажировместмость, чел. & 150 & 76 & 58 & 146 \\
\hline
\end{tabular}


ВІСНИК

ОДЕСЬКОГО НАЦІОНАЛЬНОГО МОРСЬКОГО УНІВЕРСИТЕТУ № 3 (63), 2020
HERALD

OF THE ODESSA NATIONAL

MARITIME UNIVERSITY № 3 (63), 2020

Продолжение табл. 2

\begin{tabular}{|c|c|c|c|c|}
\hline 1 & 2 & 3 & 4 & 5 \\
\hline $\begin{array}{l}\text { соотношение GT } \\
\text { к числу пассажиров }\end{array}$ & 30,5 & 27,6 & 30,3 & 20,8 \\
\hline число кают & 38 & 39 & 29 & 38 \\
\hline $\begin{array}{l}\text { специальные каюты для } \\
\text { людей с ограниченными } \\
\text { возможностями }\end{array}$ & нет & нет & нет & 1 \\
\hline $\begin{array}{l}\text { каюты 1-местные с душем } \\
\text { и туалетом }\end{array}$ & нет & 2 & нет & 1 \\
\hline $\begin{array}{l}\text { каюты 2-местные с душем } \\
\text { и туалетом }\end{array}$ & 16 & 37 & 15 & 1 \\
\hline $\begin{array}{l}\text { каюты 4-местные с душем } \\
\text { и туалетом }\end{array}$ & 16 & нет & нет & 36 \\
\hline $\begin{array}{l}\text { каюты 2-местные без } \\
\text { удобств }\end{array}$ & нет & нет & 1 & нет \\
\hline $\begin{array}{l}\text { каюты 3-местные без } \\
\text { удобств }\end{array}$ & нет & нет & 13 & нет \\
\hline $\begin{array}{l}\text { каюты 4-местные без } \\
\text { удобств }\end{array}$ & 6 & нет & нет & нет \\
\hline Экипаж, число мест & 49 & 36 & 22 & 28 \\
\hline $\begin{array}{l}\text { Грузовые трюма количе- } \\
\text { ство х } 3 \text { вместимость, м }\end{array}$ & $1 \times 208$ & $1 \times 215$ & $\begin{array}{l}1 \times 107 \\
1 \times 267\end{array}$ & $1 \times 895$ \\
\hline Грузовые краны & $1 \times 3,2 \mathrm{~T}$ & $\begin{array}{l}2 \times 2,0 \mathrm{~T} \\
1 \times 3,5 \mathrm{~T}\end{array}$ & $\begin{array}{l}1 \times 2,0 \mathrm{~T} \\
1 \times 5,0 \mathrm{~T}\end{array}$ & $\begin{array}{c}1 \times 30,5 \text { T X } \\
12 \mathrm{M} \\
(3 \mathrm{~T} \times 18 \mathrm{M})\end{array}$ \\
\hline $\begin{array}{l}\text { 20-футовые контейнеры } \\
\text { международного стандарта }\end{array}$ & нет & нет & нет & $\begin{array}{c}24 \text { (в том } \\
\text { числе } 8 \\
\text { рефрижера- } \\
\text { торных) } \\
\end{array}$ \\
\hline $\begin{array}{l}\text { Легковые автомобили } \\
\text { на палубе }\end{array}$ & & нет & & 6 \\
\hline
\end{tabular}

Например, судно этого проекта планируется задействовать для освоения Павловского рудного месторождения в западной части Новой Земли. По ее словам, вместимость судна достаточна для обеспечения одновременного нахождения в районе месторождения 500-700 работников с посменной заменой. Кроме того, судно сможет обеспечить две трети перевозок необходимых грузов обеспечения благодаря возможности перевозки контейнеров. Предполагается, что судно проекта PV22 сможет курсировать на линии Мурманск - бухта Безымянная (Новая Земля) или Архангельск - бухта Безымянная. 

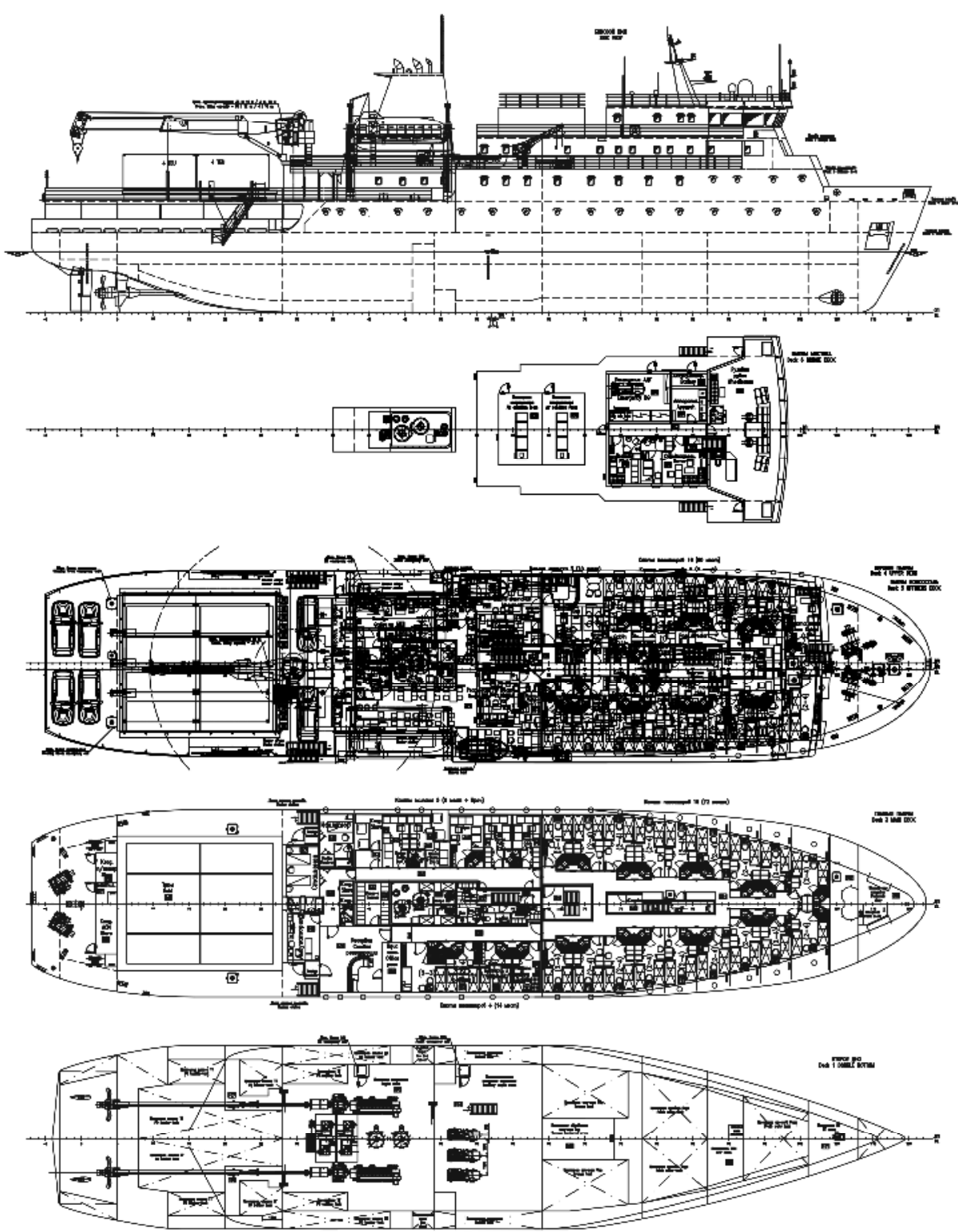

Рис. 4. Общее расположение

грузопассажирского судна проекта PV22

Такие дополнительные доходы позволят уменьшить расходы региона на содержание судов проекта PV22.

Кроме указанных имеющихся и находящихся в постройке судов обсуждаются и другие решения. Например, в начале 2020 года компания «Морспецсервис» предлагала сахалинскому правительству построить для 
организации системного грузопассажирского движения на маршрутах Южно-Курильск - Малокурильское - Курильск грузопассажирские катамараны (2-3 единицы), способные перевозить 30 пассажиров, контейнеры, генеральные грузы, автомобили. По оценкам компании на этом маршруте ежегодно перемещаются 30-35 тыс. человек. Длина наибольшая - 21,00 м. Ширина габаритная - 8,00 м. Высота борта - 2,50 м. Осадка по ЛГВЛ 1,85 м. Экипаж - 6 человек.

Кроме того, следует особо отметить действующую международную линию Корсаков - Вакканай, работающую с 1998 года (сейчас судно Eins - Soya) и обсуждаемые скоростные линии Корсаков-Монерон, Невельск-Монерон, Корсаков-Курилы.

Камчатка. Ведущее место в осуществлении грузопотоков на Камчатке принадлежит морскому транспорту, морским портам и портопунктам, которые обеспечивают около 70 \% всего грузооборота в крае. При этом в последние 12 лет морские перевозки, в том числе и пассажирские, собственным транспортом в крае сократились почти в двадцать раз.

До 1992 года пассажирские перевозки по побережью полуострова Камчатка осуществляло Камчатское морское пароходство теплоходами вместимостью до трехсот пассажиров каждый. В летнюю навигацию перевозки обеспечивалось пассажирским судном «Петропавловск» типа «Михаил Калинин». Общее количество перевезенных пассажиров за год составляло от 12 до 13 тыс. человек.

Ранее, в 1985 году на восточно-камчатской и западно-камчатской линиях перевезли 32,2 тыс. человек, в 1990 году - 20 тыс. человек. При этом если на участках Петропавловск-Камчатский - Усть-Камчатский и Петропавловск-Камчатский - Озерновский заполнение пассажирами было достаточным, то до Пахачи и Паланы судно вместимость в 300 пассажиров шло практически пустым.

Полуостров Камчатка имеет одну из самых высоких протяженностей береговой линии среди субъектов страны.

Суда должны использоваться на Западном и Восточном побережье полуострова Камчатка и обеспечивать транспортную доступность для прибрежных населенных пунктов Соболевского, Тигильского, Карагинского, Пенжинского, Алеутского, Олюторского и Усть-Болыперецкого районов, а также должна быть возможность организации транспортного сообщения с поселком Северо-Курильск (Сахалинская область).

На сегодняшний день между портами и портопунктами Камчатки, а также на Командорские острова работает одно грузопассажирское судно «Василий Завойко». Проект 16901. 2014 года постройки (Сретенский завод). Длина х ширина х высота борта х осадка: 46,30 м х 9,0 м х 3,30 м х 2,30 м. Скорость 10 узлов. Ледовый класс Iсе 2. Пассажиры - 34 в 2-х и 4-х местных каютах с туалетом и душем. Трюма объемом 264 куб. м. Грузоподъемность 180 тонн. Кран грузоподъемностью 2,6 тонны. 
Работает на линиях Петропавловск-Камчатский - село Никольское (Командорские острова) и Петропавловск-Камчатский-Ocсора, совершая около 15 рейсов в год.

Для работы между портами и портопунктами Камчатки, а также на Командорские острова 18 декабря 2019 года Окской судоверфью было заложено новое грузопассажирское судно проекта PV24 «Анатолий Чернеев».

Предназначено для перевозки 36 пассажиров, генеральных грузов, контейнеров (в т.ч. рефрижераторных) между портами и портопунктами Камчатки, а также на Командорские острова, и оборудовано грузовым краном с возможностью выполнять грузовые операции на необорудованном берегу.

Новый концепт проекта PV24 имеет улучшенные маневренные качества по сравнению с существующими судами за счет подруливающего устройства и 2 винтов. Объем двух трюмов - 1405 куб. м (против 208-215 куб. м. на существующих судах). Судно имеет возможность перевозки 27 контейнеров (18 в трюмах и 9 на палубе). Резервирование движения обеспечено за счет двухвальной двухдвигательной установки.

Длина наибольшая - 75,36 м. Длина расчетная - 70,84 м. Ширина расчетная - 13,98 м. Высота борта - 5,50 м.

Пассажиры размещаются в блок-каюте класса люкс с индивидуальным санузлом и ванной; 3 каютах класса полулюкс с индивидуальным санузлом и душем; 15 двухместных каютах с индивидуальным санузлом и душем; каюте матери и ребенка с индивидуальным санузлом и душем. Общее количество стационарных спальных мест для пассажиров - 36. Для пассажиров имеются столовая с зоной отдыха, буфет, лобби, прогулочные зоны.

При осадке 3,70 м дедвейт судна около 1357 тонн. Груз размещается в двух трюмах объемом 1405 куб. метров и на палубе. Для выгрузки груза установлен грузовой кран грузоподъемностью до 25 тонн при вылете стрелы до 16 м (против кранов грузоподъемностью 2,5-3,5 тонн на существующих судах). Мощность главных двигателей 2 х 1003 кВт. Скорость 12,0 узла. Автономность 15 суток.

Главные характеристики грузопассажирского судна проекта PV24 приведены в таблице 3.

Общее расположение грузопассажирского судна проекта PV24 приведено на рисунке 5 .

Кроме того, для круглогодичной перевозки пассажиров, автомобилей и различных грузов через протоку Озерная между посёлком УстьКамчатск и селом Крутоберегово используется паром «Капитан Драбкин». Судно проекта 618М, построено в 1971 году Канонерским судоремонтным заводом. Длина максимальная - 39,90 м. Ширина - 10,20 м. Осадка - 2,49 м. Скорость - 9,3 узла. Автономность - 6,25 суток. Грузоподъемность -5 грузовых автомашин. Пассажиров - 150 человек. 
ВІСНИК

ОДЕСЬКОГО НАЦІОНАЛЬНОГО МОРСЬКОГО УНІВЕРСИТЕТУ № 3 (63), 2020
HERALD

OF THE ODESSA NATIONAL

MARITIME UNIVERSITY

№ 3 (63), 2020

Таблица 3

Основные характеристики грузопассажирского судна проекта PV24

\begin{tabular}{|c|c|}
\hline Параметр & Значение \\
\hline Длина наибольшая, м & 75,36 \\
\hline Длина по Правилам РС, м & 70,84 \\
\hline Ширина габаритная, м & 14,06 \\
\hline Ширина расчетная, м & 13,98 \\
\hline Высота борта, м & 5,50 \\
\hline Осадка в море по ЛГВЛ, м & 3,70 \\
\hline Дедвейт при осадке по ЛГВЛ, т & 1360 \\
\hline Автономность, сут. & 15 \\
\hline Дальность плавания, миль & 5000 \\
\hline Пассажировместимость, чел. & 36 \\
\hline Общее количество кают & 20 \\
\hline одноместных блок-кают класса «люкс» & 1 \\
\hline одноместных кают класса «полулюкс» & 3 \\
\hline двухместных кают & 15 \\
\hline двухместных кают матери и ребенка & 1 \\
\hline Общее число стационарных мест & 55 \\
\hline Количество грузовых трюмов & 2 \\
\hline Объем грузовых трюмов, м $^{3}$ & 1405 \\
\hline $\begin{array}{l}\text { Интенсивность распределенной нагрузки } \\
\text { на второе дно, } \mathrm{T} / \mathrm{M}^{2}\end{array}$ & 7 \\
\hline Контейнеровместимость (трюм / палуба), TEU & $27(18 / 9)$ \\
\hline Люковые закрытия & типа «Folding» \\
\hline Грузовые краны & $\begin{array}{l}1 \text { x } 25 \text { т при вылете стрелы } \\
16 \text { м }+1 \text { х } 0,99 \text { т при вылете } \\
\text { стрелы } 7 \text { м }\end{array}$ \\
\hline $\begin{array}{l}\text { Класс Российского Морского } \\
\text { Регистра Судоходства }\end{array}$ & $\begin{array}{l}\text { KM } \otimes \text { Ice2(hull; power) } 2 \text { AUT3 } \\
\text { BWM(T) CONT (deck, cargo hold } \\
\text { No.2) DG(pack) Passenger ship }\end{array}$ \\
\hline Максимальная длительная мощность ГД, кВт & $2 \times 1003$ \\
\hline Винто-рулевой комплекс & $\begin{array}{l}2 \text { ВФШ + } 2 \text { обтекаемых подвес- } \\
\text { ных балансирных руля }\end{array}$ \\
\hline Носовое подруливающее устройство, кВт & $1 \times 185$ \\
\hline Дизель-генераторы, кВт & $3 \times 300$ \\
\hline Аварийный дизель-генератор, кВт & $1 \times 150$ \\
\hline Экипаж, чел. & 19 \\
\hline $\begin{array}{l}\text { Скорость хода при осадке 3,70 м } \\
\text { при } 85 \text { \% МДМ (не менее), узлы }\end{array}$ & 12,0 \\
\hline Спасательные шлюпки & 1 x 28 чел. + 1 x 28 чел. (дежурная) \\
\hline Рабочий катер + спасательные плоты & $1 \times 8$ чел. $+2 \times 20$ чел. \\
\hline
\end{tabular}


ВІСНИК

ОДЕСЬКОГО НАЩІОНАЛЬНОГО МОРСЬКОГО УНІВЕРСИТЕТУ
HERALD

OF THE ODESSA NATIONAL MARITIME UNIVERSITY № 3 (63), 2020
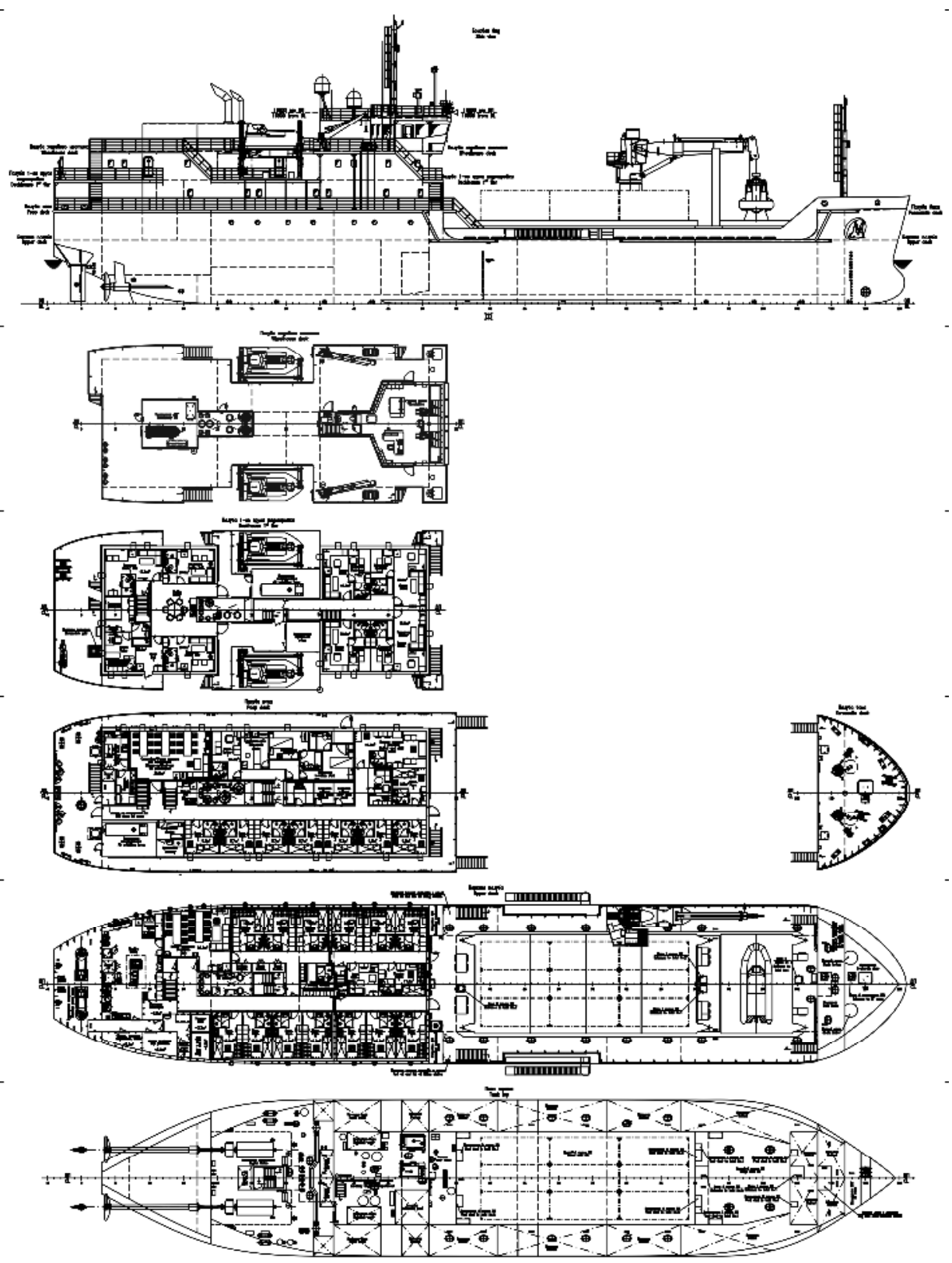

Рис. 5. Общее расположение грузопассажирского судна проекта PV24 
Как сообщал сайт Камчатского края [9], судно снабжения проекта Морского Инженерного Бюро DCV47 «Сосновка-1» [10] обеспечивало в 2017 году переправу автомобилей и грузов из Усть-Камчатска в село Крутоберегово через реку Озерная.

Переправа через реку Озерная осуществлялась ранее дизельэлектроходом «Капитан Драбкин».

7 июня 2017 года «Капитан Драбкин» был отправлен в Петропавловский порт для прохождения плановых работ. На замену в УстьКамчатский район было временно направлено судно снабжения проекта DCV47 «Сосновка-1» и судно на воздушной подушке. Однако, после начала работы на Озерной судно на воздушной подушке вышло из строя.

«После того, как паром «Капитан Драбкин» был направлен на ежегодный плановый ремонт, на замену была послана «Сосновка-1». Проблемы, конечно, есть - из-за большого числа пассажиров, людям приходилось ждать переправы. На помощь пришли рыбопромышленники, за что им спасибо. Сейчас напряженность снята, мы значительно увеличили число рейсов. Вместо 6 плановых рейсов «Сосновка» выполняет от 12 до 14, иногда 17 рейсов. Нам помогают три рыбопромышленные компании, иногда на помощь приходит четвертая. Они используют собственные суда для перевозки своих работников и жителей», - рассказал директор ГУП «Камчаттрансфлот» Вячеслав Унтилов.

По словам Губернатора Камчатского края, паром «Капитан Драбкин» построен в 1971 году и требует замены. «Капитан Драбкин», который давно работает на этой линии, изживает себя. Его содержание выливается в большие затраты для бюджета», - сказал глава региона. Глава региона отметил, что совместно с проектировщиками Минтранс проработает возможность устройства мостового сооружения через протоку Озерную. В то же время, специалисты должны в ближайшее время предложить возможные варианты с приобретением или строительством судов, которые могут прийти на смену «Капитану Драбкину».

Четыре судна проекта DCV47 типа «Сосновка» предназначены для перевозки генеральных, навалочных, контейнерных грузов на грузовой палубе, колесной и гусеничной техники накатным способом, рейдовой разгрузки и погрузки судов, доставки этих грузов на необорудованный берег с возможностью осушки на песчано-гравийном грунте и обеспечение горизонтальной выгрузки доставленных грузов с помощью носовой аппарели или судовым грузовым краном. Строились в 2011-2013 годах Сосновским судостроительным заводом в соответствии с Федеральной целевой программой «Экономическое и социальное развитие Дальнего Востока и Забайкалья на период до 2013 года».

На паромной переправе Тиличики-Корф (Олюторский район Камчатского края) работают самоходные аппарельные баржи типа «Камчатка». Длина $-25,8$ м. Ширина - 6 м. Осадка - 1,2 м. Скорость -10 узлов. Грузоподъемность 40 тонн. Пассажировместимость -25 человек. 
Так же работают 3 судна на воздушной подушке. Скоростной амфибийный катер на воздушной подушке Нептун 15 «Леопард», предназначенный для перевозки до 1450 кг груза или до 14 пассажиров. Судно относится к классу «пассажирских» СВП и предназначено для перевозки пассажиров по водоемам в летнее или зимнее время, в том числе с кратковременным выходом на берег. Обеспечивает перевозку пассажиров на линии Петропавловск-Камчатский - Микрорайон Завойко (бухта Южная). Суда на воздушной подушке «Беркут» и «Орлан», построенные на заводе ООО «Ховеркрафт» в Санкт-Петербурге. Для регулярной линии Тиличики - Корф в перерыве между навигационным сезоном и работой ледовой переправы - с декабря до начала февраля и с апреля по май включительно.

Чукотка. Морские рейсы между Анадырем и поселениями Анадырского, Иультинского, Чукотского и Провиденского районов осуществляет пассажирское судно «Капитан Сотников», построенное на Находкинском судоремонтном заводе в 1979 году. Проект 1875. Длина 38,42 м. Ширина габаритная $-6,88$ м. Высота борта - 2,9 м. Осадка по ГВЛ $-2,10$ м. Пассажиров - 74 человека.

За период с 2007 (восстановление работы судна) по 2013 годы услугами «Капитана Сотникова» воспользовались более 8200 человек.

В 2017 году в направлении Провидения и Лаврентия составили 241 человек, а в 2018 - 412 человек, в 2019-м - 497 человек. По всем направлениям из Анадыря (Беринговский, Провидения, Лаврентия, Эгвекинот) за 2017-2019 годы выросли более чем вдвое, с 687 человек в 2017 году до 1338 человек в 2019 году.

Приморский край. Местные линии. Местные линии во Владивостоке обслуживают 5 паромов, 4 пассажирских судна, 1 судно на подводных крыльях и 2 пассажирских катера.

Заключение. Развитие паромных линий на Дальнем Востоке придает импульс развитию всей транспортной инфраструктуры региона.

«Что касается Чукотки, Камчатки, Анадыря, там вообще отсутствуют железные дороги. Если будет действовать паромная переправа в Петропавловске-Камчатском или Магадане, она даст импульс для развития железнодорожной инфраструктуры. В этих портах можно построить железнодорожно-паромную переправу, куда могут прийти вагоны и далее развозиться автомобильным транспортом, а в будущем и железнодорожным», - сказал в ходе вебинара «Все паромы: Дальний Восток» член Совета директоров Международной федерации экспедиторских ассоциаций FIATA Хоким Матчанов.

Путевые, погодные и ледовые условия линий, особенности пассажиропотока и грузопотока, сопряжения с другими видами транспорта настолько отличаются в каждом дальневосточном регионе, что, по сути, привели к созданию различных концептов грузопассажирских судов, которые отвечают этим ограничениям. 
Крупным достижением является создание концепта CNF11CPD пассажирского автомобильно-железнодорожного парома-ледокола нового поколения для линии «Ванино-Холмск», который обеспечивает по сравнению с существующими судами типа «Сахалин»:

- повышенные грузовые свойства (вместимость по грузовикам в 1,8 раза больше);

- не имеет ограничений по погоде (неограниченный район плавания);

- может работать в тяжелых ледовых условиях (во льду толщиной 80 см скорость около 6-8 узлов);

- в состоянии выполнять самостоятельные (несколько раз в сутки) швартовки без буксирного обеспечения, длительное движение задним ходом по стесненной акватории порта Холмск;

- выдерживает суточный цикл кругового рейса (скорость в эксплуатации 18 узлов);

- 2-х часовую стоянку при выполнении погрузочно-разгрузочных работ.

Сегодня уже строятся для Дальнего Востока пять новых судов, спроектированных Морским Инженерным Бюро: на Амурском заводе пассажирские автомобильно-железнодорожные паромы ледокольного типа для линии Ванино-Холмск проекта CNF11CPD «Александр Деев» и «Василий Ощепков», на Невском заводе - мореходные грузопассажирские суда с хорошими ледовыми свойствами на 146 пассажиров для Сахалина проекта PV22 «Адмирал Невельской» и «Павел Леонов», на Окской судоверфи - грузопассажирское судно с малой осадкой на 36 пассажиров для Камчатки проекта PV24 «Анатолий Чернеев».

\section{СПИСОК ЛІТЕРАТУРИ}

1. Ивантер А. Восточная чрезвычайка. Стратегия развития Дальнего Востока // Эксперт. 2013. № 44 (874). С. 24-25.

2. Егоров Г.В. Паром для Сахалина // Морские вести России. 2013, № 16 (389). C. 13-15.

3. Егоров Г.В., Ильницкий И.А. Обоснование характеристик железнодорожно-автомобильно-пассажирского парома арктического класса для переправы Ванино-Холмск // Вісник OHMУ. Одеса: OHMУ, 2015. Bun. 2 (44). C. 21-51.

4. Egorov, G.V., Ilnytskyi, I.A. New Arctic class ferry for Sakhalin region // Papers of the Intern. Conf. «Ice Class Vessels》. London (UK): Royal Institution of Naval Architects, 2015. P. 23-32. 
5. Egorov, G.V., Ilnytskyi, I.A. Creation of new generation Sakhalin Arctic ferry for Vanino-Kholmsk line // Proc. of the 29th Asian Technical Exchange and Advisory Meeting on Marine Structures (TEAM'2015). Vladivostok, Russia, 2015. P. 20-28.

6. Egorov, G.V., Ilnytskyi, I.A. Design study of icebreaking ferry for Sakhalin island // Proc. of the 13th International Symposium on Practical Design of Ships and Other Floating Structures (PRADS 2016). Copenhagen, Denmark, 2016. 8 p.

7. Вебсайт Дума Сахалина [Электронный ресурс]. Режим досmyna: http://www.dumasakhalin.ru/node/2354.

8. Егоров Г.В., Хаустов А.В., Автутов Н.В. Серия многофункичиональных аварийно-спасательных судов мощзностью 4 MBm ледового плавания проекта MPSV07 типа «Спасатель Карев» // Судостроение. 2014. № 1. С. 18-25.

9. Вебсайт Правительства Камчатского края [Электронный ресурс]. Режим доступа: https://www.kamgov.ru/news/ vladimir-iluhin-porucil-prorabotat-vozmoznost-ustrojstva-iskusstvennogo-sooruzenia-cerez-protoku-ozernaa-v-krutoberegovo-10673.

10. Егоров Г.В., Ильниикий И.А., Дугужев М.Х. Суда снабжения типа «Сосновка-1» // Судостроение. 2012. № 5. С. 9-14.

\section{REFERENCE}

1. Ivanter, A. (2013). Vostochnaya chrezvychayka. Strategiya razvitiya Dalnego Vostoka [Eastern emergency. Far East development strategy]. Expert, 44 (874), 24-25 [in Russian].

2. Egorov, G.V. (2013). Parom dlya Sakhalina [Ferry for Sakhalin]. Morskie vesti Rossii [Russian maritime news], 16 (389), 13-15. [in Russian].

3. Egorov, G.V., Ilnytskiy, I.A. (2015). Obosnovaniye kharakteristik zheleznodorozhno-avtomobil'no-passazhirskogo paroma arkticheskogo klassa dlya perepravy Vanino-Kholmsk [Substantiation of characteristics of arctic-class railway-car-passenger ferry for Vanino-Kholmsk line]. Visnuk ONMU (Reporter of Odessa National Maritime University), 2 (44), 21-51 [in Russian].

4. Egorov, G.V., Ilnytskiy, I.A. (2015). New Arctic class ferry for Sakhalin region // Papers of the Intern. Conf. «Ice Class Vessels». London (UK): Royal Institution of Naval Architects, 23-32.

5. Egorov, G.V., Ilnytskiy, I.A. (2015). Creation of new generation Sakhalin Arctic ferry for Vanino-Kholmsk line // Proc. of the 29th Asian Technical Exchange and Advisory Meeting on Marine Structures (TEAM'2015). Vladivostok, Russia, 20-28. 
ВІСНИК

ОДЕСЬКОГО НАЦІОНАЛЬНОГО

МОРСЬКОГО УНІВЕРСИТЕТУ
HERALD

OF THE ODESSA NATIONAL

MARITIME UNIVERSITY

№ 3 (63), 2020

6. Egorov, G.V., Ilnytskiy, I.A. (2016). Design study of icebreaking ferry for Sakhalin island // Proc. of the 13th International Symposium on Practical Design of Ships and Other Floating Structures (PRADS 2016). Copenhagen, Denmark, 8 p.

7. Sakhalin duma website. [Electronic source]. Retrieved from: http://www.dumasakhalin.ru/node/2354.

8. Egorov, G.V., Khaustov, A.V., Avtutov, N.V. (2014). Seriya mnogofunktsional'nykh avariyno-spasatel'nykh sudov moshchnost'yu 4 MVt ledovogo plavaniya proyekta MPSV07 tipa «Spasatel' Karev» [Series of multipurpose rescue vessels with capacity of $4 \mathrm{MW}$ with arctic class of project MPSV07 of «Spasatel Karev» type]. Sudostroenie (Shipbuilding), 1, 18-24 [in Russian].

9. Kamchatka government website. [Electronic source]. Retrieved from:https://www.kamgov.ru/news/vladimir-iluhin-porucil-prorabotat-vozmoznost-ustrojstva-iskusstvennogo-sooruzenia-cerezprotoku-ozernaa-v-krutoberegovo-10673.

10. Egorov, G.V., Ilnytskiy, I.A., Duguzhev, M.Kh. (2012). Suda snabzheniya tipa «Sosnovka-1》 [Supply vessels of «Sosnovka-1》 type]. Sudostroenie (Shipbuilding), 5, 9-14 [in Russian].

Стаття надійшла до редакиії 22.04.2020

Посилання на статтю: Егоров Г.В. Исследование паромов и грузопассажирских судов для Дальнего Востока // Вісник Одеського національного морського університету: Зб. наук. праць, 2020. № 3(63). С. 21-50. DOI 10.47049/ 2226-1893-2020-3-21-50.

Article received 22.04.2020

Reference a JournalArtic: Yegorov, G. Investigation of ferries and cargo passenger vessels for Far East // Herald of the Odessa national maritime university. 2020.3(63), 21-50. DOI 10.47049/2226-1893-2020-3-21-50. 